\title{
PERSEPSI PESERTA PELATIHAN TERHADAP PEMANFAATAN GOOGLE SITES DALAM PEMBELAJARAN
}

\author{
Joko Waluyo' \\ ${ }^{1}$ Balai Diklat Keagamaan Papua, Badan Litbang dan Diklat Kementerian Agama \\ 1․masjokowa@gmail.com \\ https://doi.org/10.36052/andragogi.v9i2.246 \\ Diterima: 11 Oktober 2021 | Disetujui: 30 November 2021 | Dipublikasikan: 31 Desember 2021
}

\begin{abstract}
Abstrak
Semakin pesatnya perkembangan teknologi internet di era digital memudahkan segala aktivitas kehidupan manusia tanpa terkecuali pada bidang pelatihan yang memperoleh kemudahan akses dalam mengoptimalkan pembelajaran. Teknologi internet yang dapat diimplementasikan dalam penerapan pembelajaran di masa covid 19 salah satunya dengan memanfaatkan google sites. Tujuan penelitian ini untuk mengetahui persepsi peserta pelatihan terhadap pemanfaatan google sites dalam pembelajaran. Penelitian ini menggunakan pendekatan metode survei dengan sifat deskriptif yang memiliki tujuan untuk menggambarkan keadaan atau fenomena yang terjadi. Hasil penelitian menunjukkan bahwa Pelatihan media pembelajaran berbasis multimedia dengan google sites sangat diperlukan peserta dalam pembelajaran daring dan bermanfaat bagi peserta untuk memberikan materi pelajaran kepada peserta didik karena konten yang ada dalam google sites dapat disesuaikan dengan kebutuhan untuk proses pembelajaran.
\end{abstract}

Kata Kunci: Persepsi, pelatihan, google sites

\begin{abstract}
The rapid development of internet technology in the digital era facilitates all activities of human life without exception in the field of training which has easy access in optimizing learning. One of the internet technologies that can be implemented in the application of learning during the COVID-19 period is by utilizing Google sites. The purpose of this study was to determine the trainees' perceptions of the use of google sites in learning. This study uses a survey method approach with a descriptive nature which aims to describe the circumstances or phenomena that occur. The results of the study indicate that multimedia-based learning media training with google sites is very necessary for participants in online learning and is useful for participants to provide subject matter to students because the content on google sites can be adapted to the needs of the learning process.
\end{abstract}

Keywords: Perception, training, google sites 


\section{PENDAHULUAN}

P erkembangan zaman diiringi dengan perkembangan teknologi yang semakin maju, sehingga menuntut penggunaan metode pembelajaran yang dapat menyesuaikan dengan perkembangan tersebut. Semakin pesatnya perkembangan internet di era digital memudahkan segala aktivitas kehidupan manusia tanpa terkecuali pada bidang Pendidikan yang memperoleh kemudahan akses dalam mengoptimalkan pembelajaran jarak jauh yang terjadi saat ini (Ferismayanti, 2012). Teknologi yang dimanfaat dalam pembelajaran online tidak dapat terpisahkan dari teknologi internet. Banyak keunggulan yang diperoleh dalam pembelajaran dengan menggunakan teknologi internet diantaranya pembelajaran tidak dibatasi oleh waktu dan jarak selain itu penggunaan internet juga dapat mempermudah segala aktivitas dalam pembelajaran disaat bersamaan sedang berupaya memutus mata rantai pandemic covid 19. Keberadaan internet menjadi sangat dibutuhkan untuk tetap melaksanakan proses pembelajaran. Pemilihan media pembelajaran yang tepat sangat berpengaruhi kepada hasil belajar, hal ini yang menuntut pengajar menggunakan alternatif pembelajaran dengan teknologi yang cocok dengan kebutuhan pembelajaran.

Teknologi internet sebagai media pembelajaran online yang selalu dimanfaat oleh guru di kabupaten merauke masih didominasi dengan Whatsapp Group (WAG). Hal ini disebabkan masih kurangnya pengetahuan guru tentang teknologi internet yang dapat digunakan dalam pembelajaran. Selain itu latar belakang dan karakteristik peserta didik juga turut andil dalam keterbatasan dalam memanfaatkan teknologi internet. Pembelajaran daring yang diselenggarakan selama masa pandemi Covid19 masih kurang membanggakan disebabkkan pembelajaran berjalan hanya monoton dimana guru memberikan materi, tugas, dan penilaian melalui whatsapp yang terkesan kurang interaktif. Hal tersebut berdampak pada penilaian hasil belajar yang diperoleh peserta didik. Aktivitas guru dan peserta didik kurang sinergi tentu disebabkan karena kurangnya pemanfaatan teknologi internet dalam melaksanakan pembelajaran daring.

Teknologi yang dapat diimplementasikan dalam penerapan pembelajaran daring salah satunya dengan media website. Menurut Febrian, website adalah suatu sistem di internet yang memungkinkan siapapun agar bisa menyediakan informasi. Dengan menggunakan teknologi tersebut informasi dapat diakses selama 24 jam dalam satu hari dan dikelola oleh mesin (Widarto et al., 2012). Ini salah satu yang dapat digunakan sebagai sarana alternatif dalam pembelajaran daring untuk meningkatkan dampak posistif dari internet. Upaya untuk meningkatkan dampak positif dari pemenfaatan media website diperlukan peran tenaga pengajar dalam mengelola pembelajaran secara terarah sehingga pembelajaran berjalan dengan baik sesuai dengan tujuan pembelajaran yang ingin dicapai (Ferismayanti, 2012).

Seiring dengan perkembangan teknologi diera digital Balai Diklat Keagamaan Papua segera merespon pengembangan sistem pelatihan untuk menjawab tantangan Aparatur sipil Negara (ASN) dalam melaksanakan tugas. Tantangan revolusi industri generasi keempat yang ditandai dengan kemajuan teknologi di berbagai bidang mulai bermunculan misalnya supercomputer, robot pintar, kendaraan tanpa pengemudi, editing genetic, dan perkembangan neuroteknologi yang mengoptimalkan fungsi otak manusia. Perkembangan yang ada ukuran kemajuan suatu lembaga atau instansi tidak semata-mata diukur dari ukuran besar dan kemewahan, namun lebih kepada kelincahan merespon perkembangan teknologi menjadi kunci keberhasilan mencapai prestasi. 
Pencapaian prestasi di tengah tantangan era digital tidak dapat terpisahkan dari penggunaan teknologi media pembelajaran daring dengan memanfaatkan aplikasi yang tersedia secara gratis dari google dalam bentuk google sites. Google sites adalah salah satu media webstite yang bisa dimanfaatkan dalam proses pembelajaran. Google sites adalah sebuah website yang digunakan untuk keperluan kelompok ataupun pribadi. Google Sites merupakan cara termudah dalam membuat informasi yang bisa diakses oleh orang yang membutuhkan secara cepat, dan orang-orang dapat bekerja sama dalam situs untuk menambahkan berkas file lampiran serta informasi dari aplikasi google lainnya seperti google docs, sheet, forms, calender, awesome table dan lain sebagainya. Dengan fitur-fitur yang ditawarkan google sites dapat menunjang pembelajaran (Arief, 2017). Google sites merupakan Learning Management System (LMS) yang sistemnya sudah tersedia, tinggal mengembangkan kontennya. LMS adalah aplikasi yang digunakan untuk pembelajaran yang membutuhkan jaringan internet (Hidayati, 2018).

Google sites adalah sebuah aplikasi yang digunakan untuk membangun website dengan cara mudah dan tampilannya indah. Penggunaan website atau situs saat ini sudah dibutuhkan oleh banyak orang. Baik digunakan untuk membuat konten pribadi maupun untuk memuat informasi-informasi pendidikan maupun mengenai berbagai produk dari bisnis yang sedang dirintis. Melalui website ini, orang bisa menyimpan berbagai macam informasi untuk bisa diakses orang lain secara umum. Dengan menggunakan website, informasi yang diunggah bisa menjangkau orang dalam cakupan lebih luas. Ini baik gunakan untuk memberikan sosialisasi masyarakat tentang informasi tertentu, meningkatkan kesadaran masyarakat akan suatu produk, maupun hal-hal penting lainnya yang perlu diketahui oleh banyak orang. Dengan begitu, tidak heran jika kini website mulai dibutuhkan oleh sebagian besar masyarakat untuk kemudahan akses informasi. Situs ini pun dapat ditampilkan secara umum, sehingga dapat diakses oleh masyarakat secara luas. Cara membuat website gratis menggunakan google sites ini pun terbilang praktis dan mudah.

Google Sites salah satu produk dari google sebagai tools untuk membuat situs. Pengguna dapat memanfaatkan Google Sites karena mudah dibuat dan dikelola oleh pengguna awam. Google Sites untuk pengajar yang diperhadapkan dengan berbagai aktivitas. Seringkali pengguna berhenti di tengah jalan dalam membuat atau memelihara sebuah situs karena tantangan kompleksitas pembuatan serta memeliharaannya. Google mencoba menjawab kebutuhan tersebut dengan meluncurkan Google Sites yang tidak memerlukan bahasa program tingkat tinggi (Harsanto, 2012). Selain itu Google Sites menjadi tools yang menarik untuk dipelajari karena memiliki beberapa kelebihan diantaranya (1) gratis, (2) mudah dibuat, (3) memungkinkan pengguna dapat berkolaborasi dengan pemanfaatnya, (4) menyediakan 100 MB penyimpanan online gratis, (5) dapat ditelesuri (searchable) menggunakan mensin pencarian google (Harsanto, 2012).

Terkait dengan diberlakukannya pembelajaran daring dan memanfaatkan kelebihan-kelebihan yang dimiliki dalam mengakses Google Sites ini dapat membantu para pengajar untuk membangun sebuah website yang digunakan dalam pembelajaran. Membuat fitur-fitur apa saja yang ada pada Google sites tentu diperlukan adanya bimbingan dari fasilitator dalam bentuk pelatihan. Kondisi inilah yang direspon oleh Balai Diklat Keagamaan Papua untuk memberikan layanan yang cepat dan efisien yang sesuai dengan kebutuhan guru dilapangan dengan menyelenggarakan pelatihan media pembelajaran berbasis multimedia di Kabupaten Merauke. Melalui pelatihan inilah peserta memperoleh materi sesuai dengan kurikulum dan silabus yang 
diterbitkan oleh Pusdiklat Kementerian Agama Republik Indonesia. Muatan yang ada dalam kurikulum media pembelajaran berbasis multimedia diantaranya pemanfaatan kelas maya dengan Google Classroom, pembuatan formulir melalui google form, pemanfaatan google drive sebagai media penyimpanan, dan pemanfaatan Google Sites sebagai web blog pembelajaran daring. Google Sites dipilih sebagai web blog pembelajaran karena kontennya dapat dibuat sesuai dengan kebutuhan guru dalam mentransfer materi, tugas, penilaian kepada peserta didik dengan tampilan yang dapat disesuai sehingga lebih flekksibel.

Mengukur ketercapaian pelatihan media pembelajaran berbasis multimedia yang diselenggarakan perlu mengetahui bagaimana persepsi peserta pelatihan terhadap pemanfaatan Google Sites dalam pembelajaran. Menurut Stephen P. Robbin, persepsi adalah suatu proses pengorganisasian dan pemaknaan terhadap kesan-kesan sensori untuk memberi arti pada lingkungannya (Placas, 2015). Agar dapat individu menyadari dan mengadakan persepsi, ada beberapa syarat yang perlu dipenuhi, yaitu: (a) Adanya objek yang dipersepsi, objek menimbulkan stimulus yang mengenai alat indera atau reseptor. Stimulus dapat datang dari luar langsung mengenai alat indera, dapat datang dari dalam, yang langsung mengenai saraf penerima (sensoris), yang bekerja sebagai reseptor. (b) Alat indera, yaitu merupakan alat untuk menerima stimulus. Di samping itu harus ada saraf sensoris sebagai alat untuk meneruskan stimulus yang diterima reseptor ke pusat saraf yaitu otak sebagai pusat kesadaran dan sebagai alat untuk mengadakan respons diperlukan saraf motoris. (c) Untuk menyadari atau untuk mengadakan persepsi sesuatu diperlukan pula adanya perhatian, yang merupakan langkah pertama sebagai suatu persiapan dalam mengadakan persepsi (Yusuf, 2009).
Penelitian sebelumnya yang relevan sudah banyak dilakukan oleh peneliti terdahulu diantaranya yang pernah dilakukan oleh Ferismayanti dengan penelitian berjudul Mengoptimalkan Pemanfaatan Google Sites dalam Pembelajaran Jarak Jauh. Hasil penelitian menunjukkan manfaat penggunaan Google Sites secara optimal di antaranya adalah: mengunggah materi pembelajaran, menyimpan silabus, (3) memberikan tugas, (4) memberi pengumuman, dan (5) mengunduh dan melihat tugas siswa (Ferismayanti, 2012). Sedangkan penelitian ini lebih memfokuskan pada persepsi peserta pelatihan terhadap Google Sites yang merupakan salah satu mata pelatihan media pembelajaran berbasis multimedia. Yang diharapkan dari penelitian ini nantinya mendapatkan informasi kemampuan peserta sebelum dan setelah memperoleh materi Google Sites.

Berdasarkan latar belakang dan kajian tersebut maka yang menjadi permasalahan dalam penelitian ini adalah bagaimana persepsi peserta pelatihan terhadap pemanfaatan Google Sites dalam pembelajaran? Manfaat teoritis yang diharapkan dari penelitian ini adalah dapat memperkaya pengetahuan dan pengalaman dalam pelatihanan media pembelajaran berbasis multimedia serta dapat menambah pemahaman tentang pemanfaatan media pembelajaran Google Sites sebagai web yang bermanfaat dalam pembelajaran di sekolah/madrasah pada masa pandemi covid 19 pada khususnya dan perkembangan dunia pendidikan pada umumnya. Manfaat praktis yang diharapkan dari penelitian ini adalah terciptanya sistem pelatihan yang dapat menjawab kebutuhan peserta dilapangan dalam pemanfaatan teknologi internet sebagai media pembelajaran online.

\section{METODE PENELITIAN}

Penelitian ini menggunakan pendekatan metode survei dengan sifat deskriptif yang memiliki tujuan untuk menggambarkan 
keadaan atau fenomena yang terjadi. Arikunto dalam (Ningsih, 2020). Sudjana menyatakan bahwa penelitian deskriptif adalah pengujian yang dilaksanakan secara bertahap dimana peneliti mendeskripsikan satu atau beberapa gejala, perkara, kasus yang terjadi saat ini, mengambil masalah atau memusatkan perhatian kepada masalah-masalah aktual (Ningsih, 2020).

Penelitian ini dilakukan di Kabupaten Merauke Provinsi Papua pada saat peneliti menyampaikan materi pemanfaatan Google Sites sebagai web blog. Pelatihan media pembelajaran berbasis multimedia yang diselenggarakan mulai tanggal 26 April sampai dengan 01 Mei 2021. Sedangkan materi pelatihan Google Sites dilaksanakan pada hari kamis dan jumat tanggal 29 dan 30 April 2021. Adapun peserta pelatihan berjumlah 25 guru madrasah dan guru pendidikan agama (multiagama) pada sekolah.

Pengumpulan data menggunakan yaitu angket yang terdiri dari tanggapan atas pernyataan untuk mengetahui persepsi peserta pelatihan secara kuantitatif dan tanggapan secara uraian untuk mengetahui tanggapan yang belum terakomodir dalam pernyataan pilihan. Data yang diperoleh dari peserta pelatihan melalui google form dan bisa langsung diunduh sekaligus hasil analisisnya yang berupa angka-angka dan presentasenya. Hasil analisis kuantitatif google form kemudian dilakukan analisis deskriptif untuk pembahasannya.

\section{TEMUAN DAN PEMBAHASAN}

\section{Temuan}

Berdasarkan tanggapan yang terhimpun dari 25 peserta pelatihan melalui google form didapat hasil analisisnya secara langsung. Hasil angket untuk mengetahui penerapan pembelajaran Google Sites pada pelatihan media pembelajaran berbasis multimedia yang diselenggarakan di kabupaten merauke.
Jawaban dari pernyataan yang ada pada angket dapat dituliskan sebagai berikut:

1) Kompetensi saya dalam menggunakan Google Sites sebelum mengikuti pelatihan masih sangat kurang.

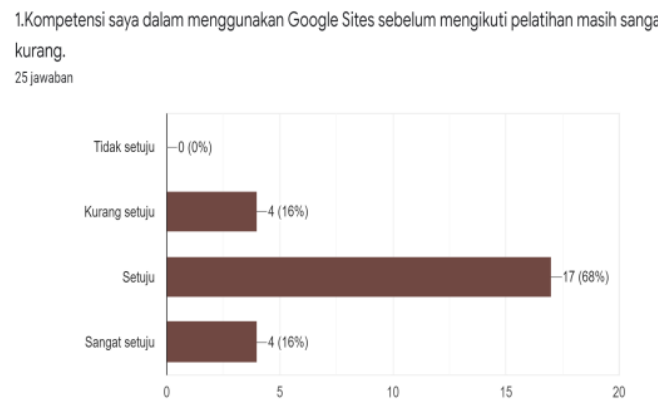

Grafik 1. Respon terhadap pernyataan 1

2) Sebelum adanya pelatihan multimedia ini, saya belum pernah menggunakan Google Sites sebagai media pembelajaran.

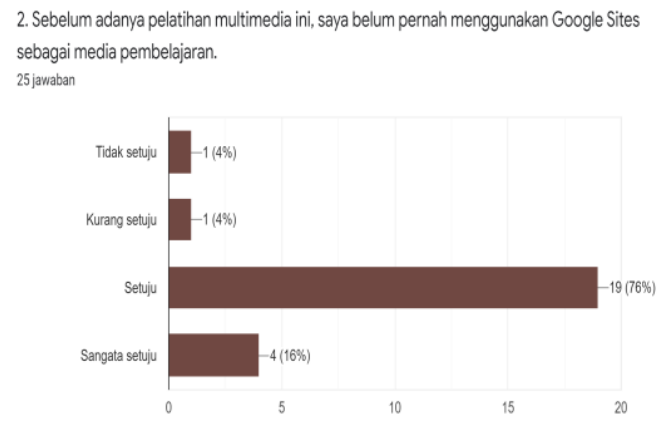

3) Sarana prasarana di dalam kelas yang dibutuhkan untuk mendukung pelaksanaan pelatihan multimedia (Google Sites) tersedia dengan baik.

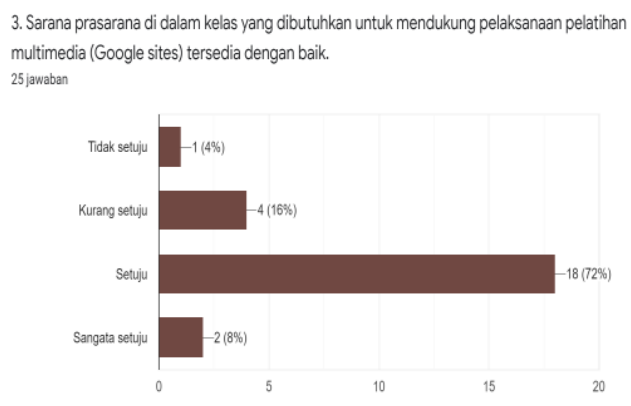


4) Bahan ajar dari narasumber tentang materi Google Sites tersedia dengan baik.

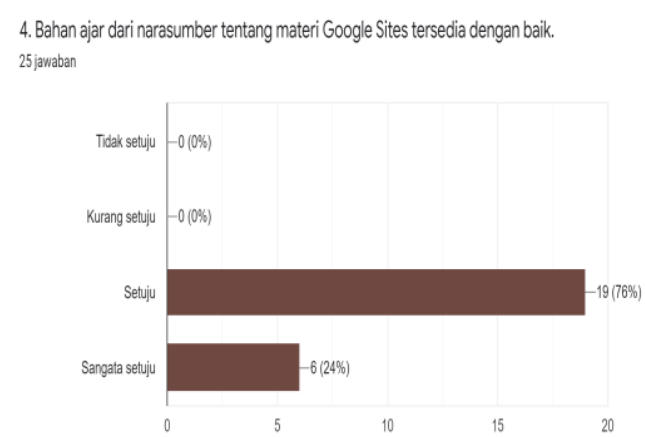

5) Mata pelatihan Google Sites dalam pelatihan media pembelajaran multimedia sangat saya butuhkan.

5. Mata pelatihan Google Sites dalam pelatihan media pembelajaran multimedia sangat saya butuhkan.

25 jawaban

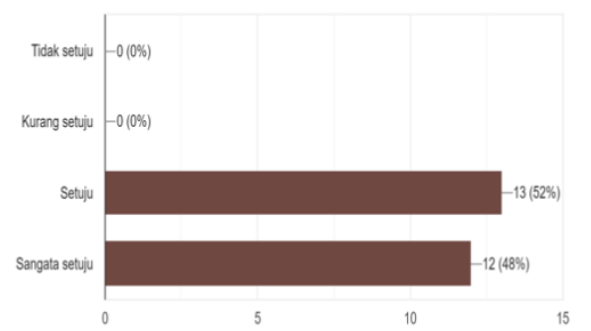

6) Waktu yang tersedia untuk menerima materi Google Sites sudah sesuai.

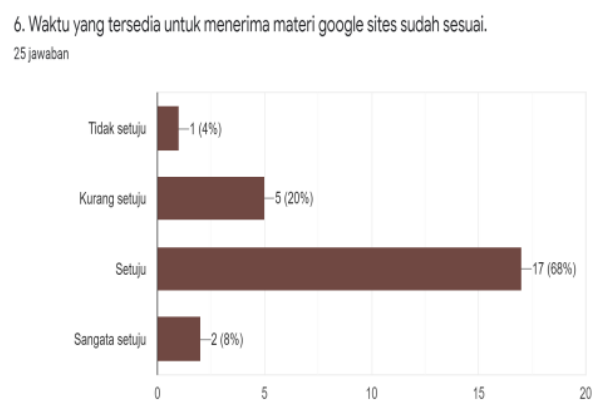

7) Pelaksanaan pelatihan media pembelajaran berbasis multimedia (Google Sites) berlangsung dengan baik.

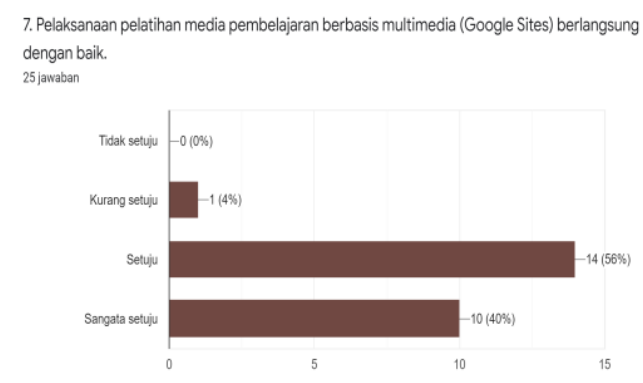

8) Saya memahami dengan baik materi Google Sites yang disampaikan narasumber.

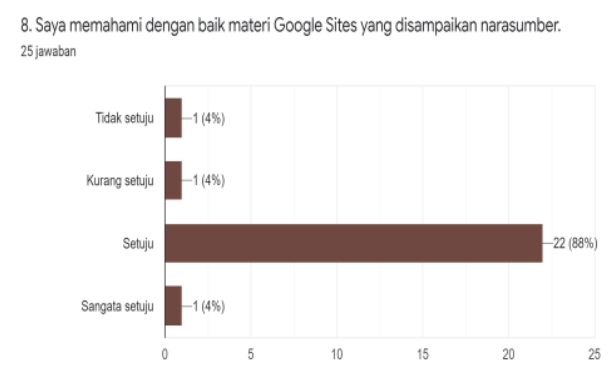

9) Penguasaan saya tentang Google Sites setelah mengikuti pelatihan meningkat.

9. Penguasaan saya tentang Googe Sites setelah mengikuti pelatihan meningkat 25 jawaban

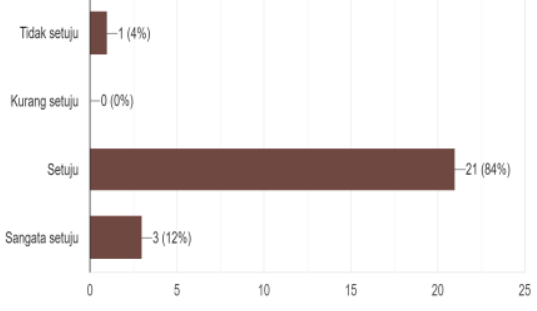


10) Saya sangat membutuhkan penerapan Google Sites sebagai media pembelajaran online.

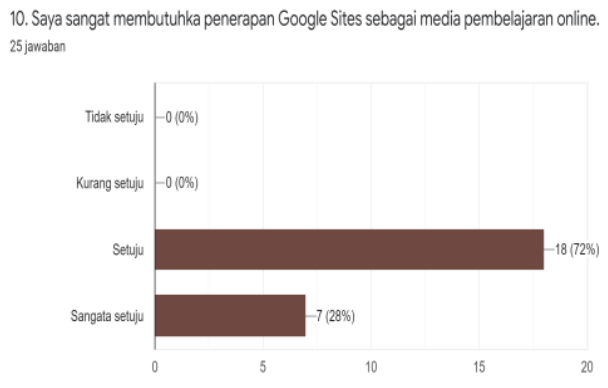

11) Saya sangat membutuhkan tindak lanjut pelatihan yang memanfaatkan media ICT.

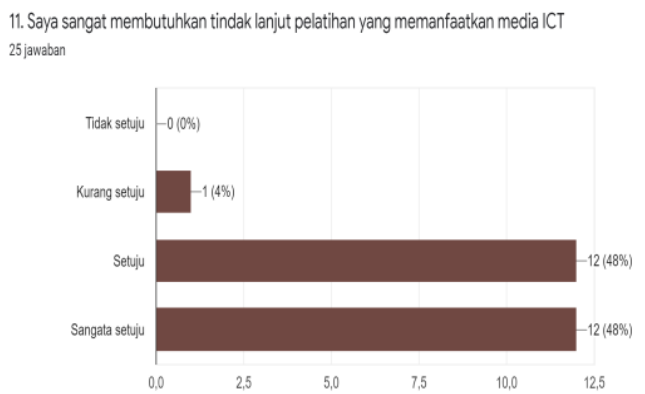

\section{Pembahasan}

Penelitian dilakukan kepada seluruh peserta yang mengikuti pelatihan media pembelajaran berbasis multimedia di Kabupaten Merauke. Peserta yang telah mengisi form berjumlah 25 orang.

Sangat kurangnya kompetensi peserta sebelum mengikuti materi Google Sites menunjukkan $16 \%$ sangat setuju, $68 \%$ setuju, dan $16 \%$ kurang setuju. Hal ini dapat dijelaskan bahwa kompetensi peserta sebelum mendapat materi termasuk dalam kategori masih kurang. Kurangnya kompetensi guru tentang Google Sites disebabkan belum pernah mendapatkan bimbingan pemanfaatan media pembelajaran tersebut. Guru masih mendominasi menggunakan media whatsapp untuk memberikan materi, tugas, dan soal sebagai penilaian pembelajaran. Pemanfaatan Whatsapp sebagai media pembelajaran online masih terus diminati oleh guru karena lebih sederhana dalam penggunaannya. Whatsapp banyak digunakan oleh pengajar pada awal masa pandemi covid 19, di mana hasil kajian yang dilakukan oleh Sulia Ningsih menunjukkan Whatsapp berada pada posisi urutan kedua $(91,9 \%)$ setelah Google Classrom media online yang digunakan dalam pembelajaran daring (Ningsih, 2020).

Respon dari peserta tentang pemanfaatan Google Sites sebelum mengikuti pelatihan 16\% sangat setuju, $76 \%$ setuju, dan $4 \%$ kurang setuju ini menunjukkan guru belum menggunakan media pembelajaran online yang bervariasi.

Selama berlangsungnya proses pembelajaran ketersediaan sarana dan prasarana yang terdiri dari kenyamanan ruang kelas, jaringan internet yang tersedia, perangkat komputer yang ada $2 \%$ menyatakan sangat setuju, $72 \%$ setuju, $4 \%$ kurang setuju, dan $1 \%$ tidak setuju. Namun selama proses pembelajaran berlangsung ada beberapa peserta yang mengalami kendala terkait perangkat yang tidak support menjalankan aplikasi.

Ketersediaan bahan ajar yang disajikan oleh narasumber sudah tersedia dengan baik. Sebanyak $24 \%$ responden sangat setuju, $76 \%$ setuju. Hal ini menunjukkan bahwa narasumber telah menyiapkan bahan ajar yang mudah dipahami oleh peserta pelatihan. Narasumber mengawali pembelajaran dengan menyampaikan tujuan pembelajaran, menjelaskan konsep dan fitur-fitur yang terdapat pada Google Sites, dan memberikan tutorial langkah-langkah membuat Google Sites sebagai web blog, serta menuntun peserta sampai terbentuknya fitur yang dibutuhkan untuk pembelajaran yang terdiri dari halaman muka (home), absen online, materi (buku elektronik dan video),tugas, dan penilaian.

Peserta pelatihan sangat membutuhkan materi-materi terkait dengan media 
pembelajaran berbasis multimedia hal ini ditunjukkan dengan respon peserta dimana $48 \%$ menyatakan sangat setuju dan $52 \%$ setuju membutuhkan materi Google Sites sebagai media pembelajaran online. Sebelum masuk pada pembuatan website peserta dibimbing terlebih dahulu tentang beberapa aplikasi yang nantinya digunakan dalam pembuatan website diantaranya pembuatan absen online, pembuatan kuisioner atau penilaian melalui google form, cara meng-upload file dan folder ke dalam media penyimpanan Google Drive, dan memberikan identitas semua bahan ajar, tugas, penilaian yang akan diberikan kepada peserta didik. Materi-materi dimanfaatkan saat pembuatan website melalui Google Sites, membuat tampilan website menjadi menarik dan interaktif saat proses pembelajaran berlangsung.

Ketersediaan waktu pembelajaran materi Google Sites sudah menurut $8 \%$ peserta menyatakan sangat setuju, $68 \%$ setuju, $20 \%$ kurang setuju, dan $4 \%$ tidak setuju. Dari tanggapan reponden dengan ketersediaan waktu 15 jam pelajaran yang tertuang dalam kurikulum dan dan silabus untuk menerima materi Google Sites perlu ditambah, karen tidak semua peserta memiliki kemampuan yang sama dalam memahami dan menguasai media teknologi informasi dan teknologi. Namun dengan bimbingan dan pendampingan narasumber diakhir dari pembelajaran semua peserta sudah memiliki website yang siap digunakan untuk pembelajaran. Walaupun ada peserta yang perlu menyempurnakan kontenkonten di websitenya sebelum digunakan dalam proses pembelajaran daring.

Respon peserta tentang proses pembelajaran google sites dapat berlangsung dengan baik. Dari kuisioner yang terhimpun $40 \%$ sangat setuju, $56 \%$ setuju, $4 \%$ kurang setuju. Ini menunjukkan peserta merespon baik materi yang diberikan. Peserta sangat antusias selama mengikuti proses pembelajaran. Peserta menyadari di saat kondisi pandemi covid 19 dengan diberlakukannya pembatasan aktivitas manusia maka guru dituntut memiliki kreativitas dan inovasi untuk memberikan materi pembelajaran yang menarik kepada peserta didik, untuk menghindari stigma pembelajaran daring membebani orangtua di rumah. Dengan memberikan pembelajaran yang sesuai dengan karakteristik peserta didik maka diharapkan hasil belajar daring akan semakin baik.

Respon peserta tentang memahami materi yang disampaikan oleh narasumber dengan baik menunjukkan $4 \%$ menyatakan sangat setuju, $88 \%$ setuju, $4 \%$ kurang setuju, $4 \%$ tidak setuju. Pemanfaatan media pembelajaran Google Sites perlu mendapat bimbingan dari fasilitator. Hal ini dilakukan karena tidak semua peserta pelatihan memiliki penguasaan ICT yang sama. Bimbingan dilakukan untuk memastikan semua peserta dapat memahami langkah-langkah membuat website dan memfungsikan website tersebut dalam pembelajaran daring.

Penguasaan peserta setelah mengikuti pelatihan tentang Google Sites semakin meningkat. Hal tersebut mendapat respon 125 sangat setuju, $84 \%$ setuju, dan $4 \%$ tidak setuju. Setelah dilaksanakan pembelajaran dengan teknik bimbingan peserta dapat merasakan penambahan pengetahuan tentang pemanfaatan Google Sites sebagai media pembelajaran. Hal ini dapat dipertegas saat dilakukan penilaian kepada peserta melalui ujian praktek pemanfaatan pada umumnya peserta sudah mengetahui langkah-langkah pembuatan dan memanfaatkan google sites dalam pembelajaran. Walaupun ada 1 orang peserta yang harus mendapatkan bimbingan tambahan.

Pemanfaatan media pembelajaran google sites sangat diperlukan guru saat menyampaiakan materi pelajaran. Sebanyak $28 \%$ responden sangat setuju dan $72 \%$ setuju. Dengan demikian menunjukkan bahwa peserta membutuhkan google sites sebagai media pembelajaran selama proses belajar mengajar dilakukan secara daring. Selain itu, jawaban 
reponden tentang apakah sangat membutuhkan tindak lanjut pelatihan media pembelajaran ICT sebanyak $48 \%$ menyatakan sangat setuju, $48 \%$ setuju, dan $4 \%$ kurang setuju.

Dari wawancara yang dilakukan dapat disimpulkkan setelah memperoleh mengetahui cara membuat website melalui google sites, peserta akan mengimplementasikan dalam pembelajaran untuk membuat pembelajaran daring yang lebih interaktif. Berharap adanya pelatihan sejenis agar semakin memperkaya ilmu dengan pemanfaatan media pembelajaran berbasis multimedia.

\section{PENUTUP}

\section{Simpulan}

Dari hasil penelitian yang dilakukan dapat disimpulkan bahwa:

1. Peserta memberikan respon yang baik dengan adanya pelatihan media pembelajaran pemanfaatan Google Sites.

2. Media pembelajaran Google Sites dapat digunakan dalam pembelajaran sebagai alternatif memberikan materi pelajaran kepada peserta didik.

\section{Rekomendasi}

Peserta pelatihan sebagai guru dapat menerapkan pembelajaran dengan menggunakan google sites sebagai alternatif pembelajaran daring karena memiliki kontenkonten yang dapat disesuaikan dengan kebutuhan materi pelajaran sehingga peserta didik tidak mudah bosan dan termotivasi untuk mengikuti pelajaran. 


\section{DAFTAR PUSTAKA}

Arief, R. (2017). Aplikasi Presensi Siswa Online Menggunakan Google Forms, Sheet, Sites, Awesome Table dan Gmail. Seminar Nasional Sains Dan Teknologi Terapan V 2017, 137-144. https://core.ac.uk/download/pdf/289705217.pdf

Ferismayanti. (2012). Mengoptimalkan Pemanfaatan Google Sites dalam Pembelajaran Jarak Jauh Oleh: Ferismayanti, M.Pd. 1-12.

Harsanto, B. (2012). Panduan E-Learning Menggunakan Google Sites. 3.

Hidayati, R. (2018). Peran Widyaiswara Dalam Pengembangan Kompetensi Melalui E-learning Menuju ASN 4.0. E-Prosiding Seminar Nasional "Inovasi Menuju Corporate University" ISSN: 26230267.

Ningsih, S. (2020). Persepsi Mahasiswa Terhadap Pembelajaran Daring Pada Masa Pandemi Covid -19. JINOTEP (Jurnal Inovasi Dan Teknologi Pembelajaran): Kajian Dan Riset Dalam Teknologi Pembelajaran, 7(2), 124-132. https://doi.org/10.17977/um031v7i22020p124

Placas, C. D. E. (2015). No analisis Persepsi Konsumen Pada Produk Perumahan Di PT. Cipta Jaya Inhil Di Tembilahan.Title. 2015(1), 1-239.

Widarto, Pardjono, \& Widodo, N. (2012). Pengembangan model pembelajaran. Cakrawala Pendidikan, XXXI(3), 409-423.

Yusuf, N. (2009). Nurminah Yusuf Magister Administrasi Rumah Sakit Program Pasca Sarjana. 